Wydziat Nauk Ekonomicznych i Zarzqdzania UMK

* Katedra Zarzadzania Finansami

** Katedra Ekonometrii i Statystyki

\author{
Ewelina Sokołowska* \\ Jerzy Witold Wiśniewski**
}

\title{
FISKALNE OBCIĄŻENIA ZATRUDNIENIA W MAŁYM PRZEDSIĘBIORSTWIE NA TLE WYDAJNOŚCI PRACY
}

Z a ry s treści. Znajomość prawidłowości kształtowania się kosztów pracy w firmie, w tym fiskalnych kosztów zatrudnienia, pozwala na podejmowanie racjonalnych decyzji dotyczących wszystkich ważnych obszarów życia przedsiębiorstwa. Informacje o tego typu mechanizmach winny być przedmiotem monitorowania przez organy władzy, które mogą modyfikować przepisy prawa w taki sposób, by powstrzymywać ewentualne upadłości firm, w tym również małych.

Przedstawione w niniejszej pracy trendy i mechanizmy występują w przedsiębiorstwach dość powszechnie. Kierunki następujących zmian winny nie tylko niepokoić świat polityki, ale też skłonić do refleksji nad stanem polskiej drobnej przedsiębiorczości.

W niniejszej pracy omówiono trendy i mechanizmy wahań fiskalnych obciążeń pracy w małym przedsiębiorstwie wytwórczym na tle zmian zespołowej wydajności pracy. Badania empiryczne zostały przeprowadzone na podstawie danych miesięcznych z lat 1996-2006. Narzędziem badawczym jest dynamiczny model ekonometryczny.

Słow a kluczowe: podatki, zatrudnienie, wydajność pracy, małe przedsiębiorstwo.

\section{WPROWADZENIE}

Przełom XX i XXI wieku w Polsce charakteryzował się systematycznym wzrostem stopy bezrobocia. Istotną rolę w utrzymywaniu się tego trendu odgrywały rosnące koszty pracy, w tym fiskalne obciążenia płac w przedsiębiorstwach. Były one szczególnie dotkliwe dla małych przedsiębiorstw. Zahamowanie 
procesu wzrostu stopy bezrobocia nastapiło po akcesji naszego państwa do Unii Europejskiej, głównie za sprawą emigracji zarobkowej Polaków. Rosnące bezrobocie było następstwem spadku zapotrzebowania na pracę $\mathrm{w}$ polskich przedsiębiorstwach. Poprawiała się przy tym efektywność ekonomiczna firm, przede wszystkim dzięki poprawie technicznego ich wyposażenia, uzyskanego drogą inwestycyjną. Polityka fiskalna państwa w tym okresie wyraźnie sprzyjała ograniczaniu popytu na pracę $\mathrm{w}$ przedsiębiorstwach.

W niniejszej pracy przedstawione zostaną trendy i mechanizmy wzrostu fiskalnych obciążeń pracy $\mathrm{w}$ małym przedsiębiorstwie produkcyjnym ${ }^{1}$ na tle zmian zespołowej wydajności pracy. Badania empiryczne przeprowadzone zostały na podstawie danych miesięcznych z lat 1996-2006. Narzędziem badawczym jest dynamiczny model ekonometryczny.

\section{TENDENCJE FISKALNYCH OBCIĄŻEŃ PRACY W MAŁYM PRZEDSIĘBIORSTWIE}

W małym przedsiębiorstwie dominuje zasada umawiania się pracodawcy z pracownikiem na wysokość wynagrodzenia netto. W rzeczywistości pracownik, zwłaszcza nieposiadający wysokich kwalifikacji, nie interesuje się kosztem pracy, czy też wielkością swojej płacy brutto. Motywująca (lub też nie) może być dla niego tylko płaca netto. Dlatego więc wszelkie narzuty na płace są wyłącznie „zmartwieniem” pracodawcy.

W niniejszej pracy zaprezentowane zostaną fiskalne obciążenia zatrudnienia w małym przedsiębiorstwie, na które składają się: składka na ubezpieczenie społeczne, składka na fundusz gwarantowanych świadczeń pracowniczych, ubezpieczenie zdrowotne oraz podatek dochodowy od osób fizycznych. Zmiany sumarycznej wartości wynikających z wyżej wymienionych kwot w złotych w przeliczeniu na 1 zatrudnionego w pełnym wymiarze czasu pracy prezentuje wykres 1. Są to wielkości nominalne w cenach bieżących. Wykres 2. przedstawia jednopodstawowy indeks dynamiki fiskalnych kosztów pracy, wyrażony procentowo, przy czym stałą podstawą są fiskalne koszty pracy ze stycznia 1996 roku (styczeń $1996=100 \%$ ). Dostrzega się wyraźny wzrost obciążeń przedsiębiorstwa fiskalnymi kosztami pracy, przy czym przy końcu 2006 roku były one nominalnie ponad czterokrotnie wyższe w porównaniu z początkiem 1996 roku. Należy jednak uwzględnić w rachunku stopę inflacji. Wykres 3. prezentuje jednopodstawowy indeks cen w okresie: styczeń 1996 - grudzień 2006, przy czym ceny ze stycznia 1996 roku są bazą $(100 \%)$.

1 Przedsiębiorstwo YPSYLON funkcjonuje w branży poligraficzno-wydawniczej, sprzedając swoje wyroby hurtownikom na obszarze całej Polski. 


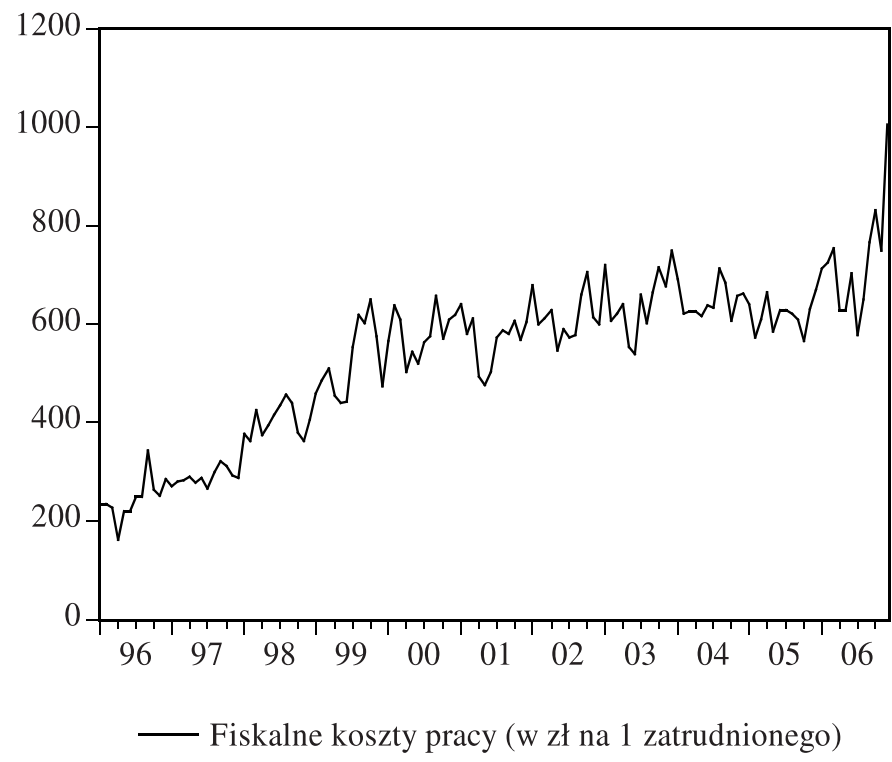

Wykres 1 . Fiskalne koszty zatrudnienia w małym przedsiębiorstwie w przeliczeniu na jednego pełnozatrudnionego w okresie od stycznia 1996 do grudnia 2006 roku

Źródło: obliczenia własne na podstawie informacji z przedsiębiorstwa.

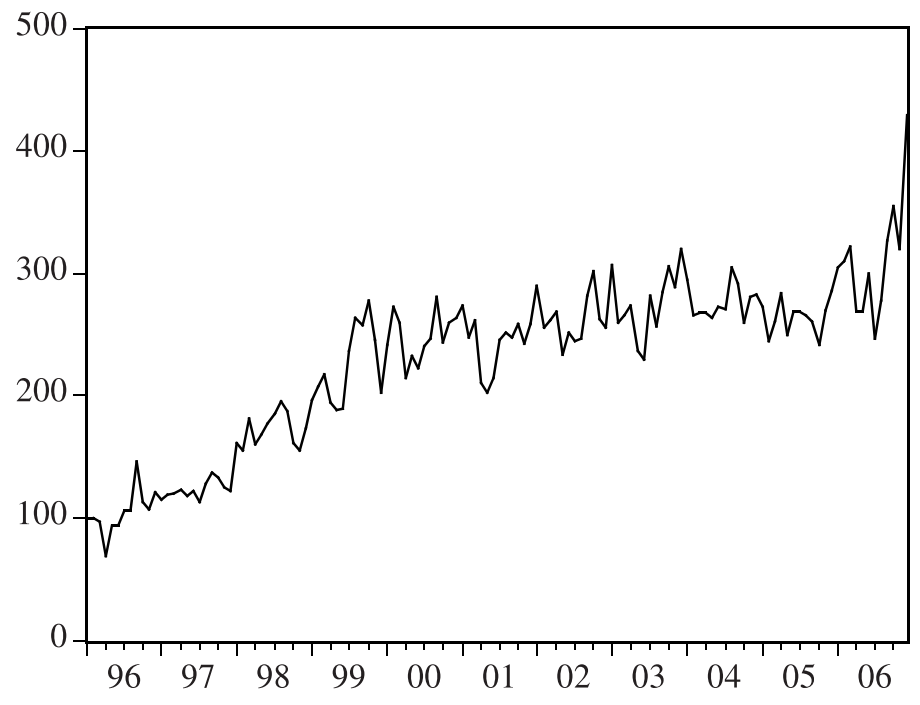

— Dynamika fiskalnych kosztów pracy na 1 zatr. $(01.1996=100)$

Wykres 2. Dynamika fiskalnych kosztów pracy/1 zatrudnionego $(01.1996=100 \%)$

Źródło: obliczenia własne na podstawie informacji z przedsiębiorstwa. 


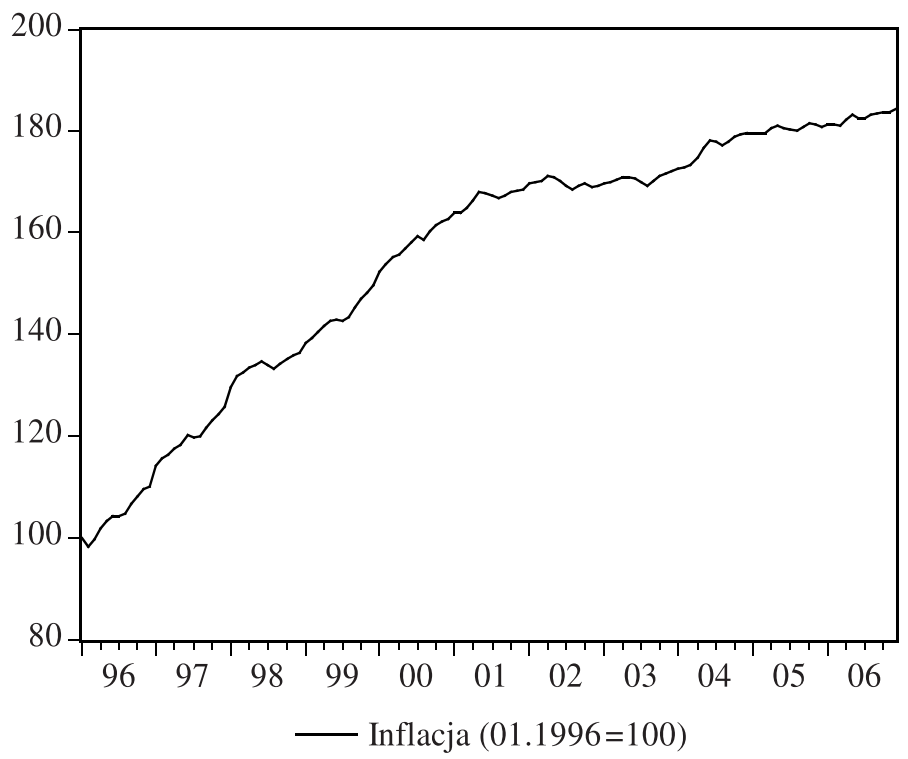

Wykres 3. Dynamika cen towarów i usług konsumpcyjnych w Polsce $(01.1996=100 \%)$ Źródło: obliczenia własne na podstawie danych Głównego Urzędu Statystycznego.

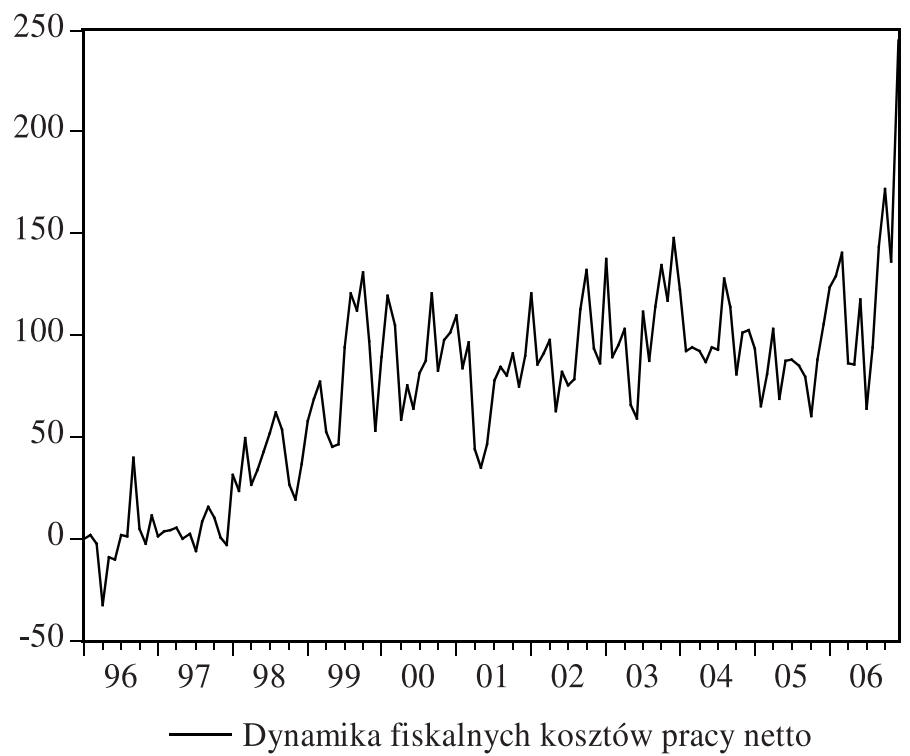

Wykres 4. Zmiany realnych fiskalnych kosztów pracy na 1 zatrudnionego (\%) w okresie od stycznia 1996 do grudnia 2006 roku

Źródło: obliczenia własne na podstawie informacji z przedsiębiorstwa oraz danych GUS. 
Wykres 4. przedstawia dynamikę netto fiskalnych kosztów zatrudnienia ${ }^{2}$. Wskaźnik ten stanowi różnicę pomiędzy jednopodstawowym ${ }^{3}$ indeksem dynamiki fiskalnych nominalnych kosztów zatrudnienia i jednopodstawowym indeksem dynamiki cen towarów i usług. Informuje on o tym, o ile procent indeks dynamiki fiskalnych kosztów netto (in plus lub in minus) różni się od indeksu dynamiki cen.

Zauważa się, że w pierwszych miesiącach 1996 roku dynamika fiskalnych kosztów zatrudnienia była niższa od dynamiki cen. Od połowy 1996 roku dynamika fiskalnych kosztów zatrudnienia znacznie przekraczała dynamikę cen. W rezultacie w drugiej połowie 2006 roku indeks dynamiki fiskalnych kosztów zatrudnienia był o ponad 200 punktów procentowych wyższy od dynamiki cen. Oznaczało to znaczący wzrost całkowitych kosztów pracy netto w latach 1996-2006. Jeśli przedsiębiorstwo nie zwiększyło odpowiednio wydajności pracy, to następstwem zaobserwowanego trendu mogło być ograniczenie jego siły konkurencyjnej w obszarze cen zbytu.

Występujące zmiany w fiskalnych obciążeniach zatrudnienia należy porównać z wahaniami zespołowej wydajności pracy. Warto zadać pytanie o udział fiskalnych kosztów zatrudnienia (w przeliczeniu na 1 zatrudnionego) w przeciętnej wydajności pracy miesięcznie. Wykres 5. ilustruje zmiany tego udziału w okresie 1996-2006. Dostrzega się systematyczny wzrost tegoż udziału, z określonymi wahaniami okresowymi.

W ciągu lat 1996-2006 procentowy udział fiskalnych kosztów zatrudnienia W wydajności pracy systematycznie wzrastał. W początkowym okresie wynosił on kilka procent, rosnąc do poziomu kilkunastu procent po roku 2000. Średnia wartość tego udziału wyniosła ponad 10\%. Najwyższe wskaźniki udziału pojawiły się od 2005 roku, przy czym maksymalny udział wyniósł 25,8\%. Szczegółowe informacje o strukturze udziału fiskalnych kosztów zatrudnienia w wydajności pracy prezentuje wykres 6 . Występująca tendencja zagraża więc - nawet w nieodległej perspektywie - istnieniu przedsiębiorstwa.

2 Problemy związane z fiskalnymi konsekwencjami zapotrzebowania na pracę w małym przedsiębiorstwie zaprezentowaliśmy wcześniej w pracy Wiśniewska, Wiśniewski(2007), SGH.

3 Podstawą jest styczeń 1996 r., w którym oba indeksy osiągają wartość 100\%, wskutek czego ich różnica wynosi $0 \%$. 


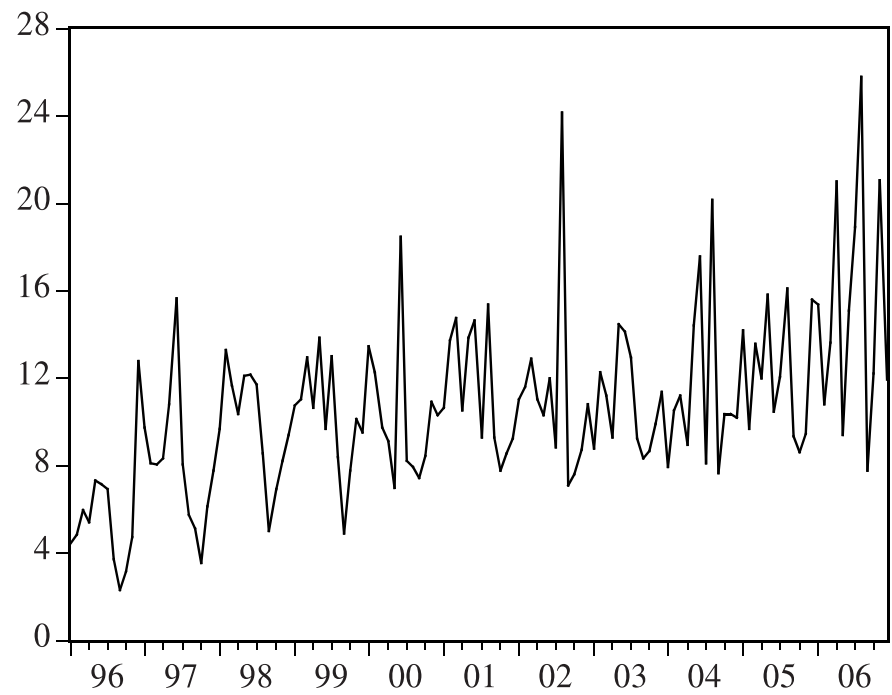

— Udział fisk.kosztów zatr. w wyd.pracy

Wykres 5. Procentowy udział fiskalnych kosztów zatrudnienia w wydajności pracy (miesięcznie w latach 1996-2006)

Źródło: obliczenia własne na podstawie informacji z przedsiębiorstwa.

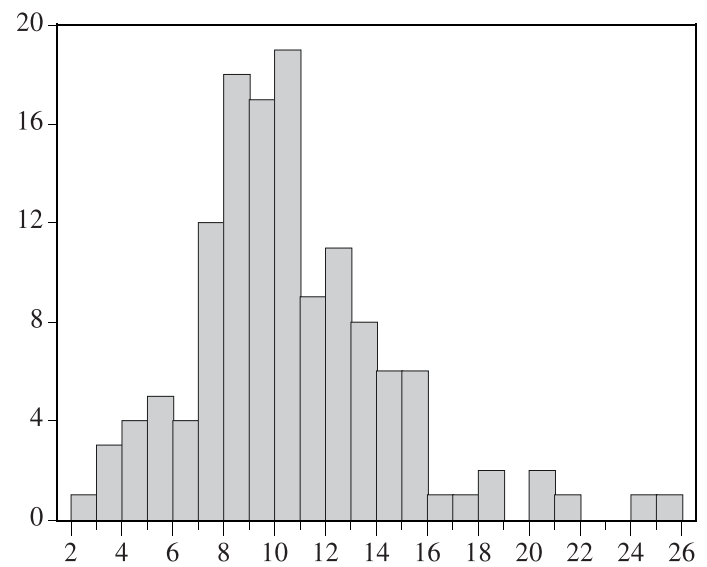

Szereg: Udz.fisk.kosztów zatr. w wyd.pracy (\%) Dane z okresu: 1996:01 2006:12

Obserwacji: $n=132$

Średnia $\quad 10.60345$

Mediana $\quad 10.21298$

Maximum 25.79470

Minimum 2.278107

Odch. stand. 3.962041

Skośność $\quad 0.981249$

Kurtoza $\quad 4.989765$

Wykres 6. Struktura udziału fiskalnych kosztów zatrudnienia w wydajności pracy (miesięcznie w latach 1996-2006)

Źródło: obliczenia własne na podstawie informacji z przedsiębiorstwa. 


\section{MECHANIZMY ZMIENNOŚCI FISKALNYCH OBCIĄŻEŃ ZATRUDNIENIA W MAŁYM PRZEDSIĘBIORSTWIE}

Podjęto próbę opisu mechanizmu zmienności fiskalnych kosztów zatrudnienia brutto i netto w małym przedsiębiorstwie. Postawiono hipotezę o zależności autoregresyjnej 12 rzędu z trendem kwadratowym. W rezultacie eliminacji zmiennych statystycznie nieistotnych ${ }^{4}$ otrzymaliśmy następujący autoregresyjny model empiryczny, opisujący zmienność jednopodstawowego indeksu dynamiki fiskalnych kosztów zatrudnienia (miesięcznie na 1 pełnozatrudnionego w cenach bieżących) $)^{5}$ :

$$
\begin{aligned}
& \mathrm{fdb}_{\mathrm{t}}=21,95+0,599 \mathrm{fdb}_{\mathrm{t}-1}-0,253 \mathrm{fdb}_{\mathrm{t}-5}+0,347 \mathrm{fdb}_{\mathrm{t}-6}+0,246 \mathrm{fdb}_{\mathrm{t}-11}+\mathrm{u}_{1 \mathrm{t}}, \\
& \begin{array}{llll}
(2,397) & (7,886) \quad(2,484) & (3,606) & (3,116)
\end{array} \\
& \mathrm{R}_{1}^{2}=0,855 ; \mathrm{DW}_{1}=1,910 ; \mathrm{Su}_{1}=22,6
\end{aligned}
$$

W modelu (1) występują:

$\mathrm{fdb}_{\mathrm{t}}$ - indeks dynamiki wartości fiskalnych kosztów pracy miesięcznie w złotych na 1 pełnozatrudnionego $\mathrm{w}$ miesiącu $\mathrm{t}$,

$\mathrm{fdb}_{\mathrm{t}-1}, \mathrm{fdb}_{\mathrm{t}-5}, \mathrm{fdb}_{\mathrm{t}-6}, \mathrm{fdb}_{\mathrm{t}-11},-$ indeks dynamiki wartości fiskalnych kosztów pracy miesięcznie w złotych na 1 pełnozatrudnionego opóźniony odpowiednio o 1 miesiąc, 5, 6 i 11 miesięcy,

$\mathrm{u}_{1 \mathrm{t}}-$ reszty równania,

$\mathrm{R}_{1}^{2}$ - kwadrat współczynnika korelacji wielorakiej równania (1),

$\mathrm{DW}_{1}$ - wartość statystyki Durbina i Watsona,

$\mathrm{Su}_{1}$ - błąd standardowy reszt pierwszego równania.

W modelu (1) nie występuje trend, bowiem zmienna czasowa - jako statystycznie nieistotna - została wyeliminowana. Natomiast istotne okazały się zależności autoregresyjne pierwszego, piątego, szóstego i jedenastego rzędu. Najbardziej intensywna jest autoregresja pierwszego rzędu, mająca charakter nawiązania sekwencyjnego. Analogiczne nawiązanie sekwencyjne występuje w odniesieniu do opóźnień o 6 i 11 miesięcy. Autoregresja piątego rzędu wskazuje na przemienność wahań indeksu dynamiki co 5 miesięcy, czego konsekwencją jest zmienność znaku. Wskutek tego rezultatem jest przemienne zwiększanie indeksu a następnie po 5 miesiącach jego zmniejszanie mnożnikiem $(-0,253)$.

${ }^{4}$ W świetle testu t-Studenta.

5 Pod ocenami parametrów strukturalnych podane są empiryczne wartości statystyk t-Studenta. 


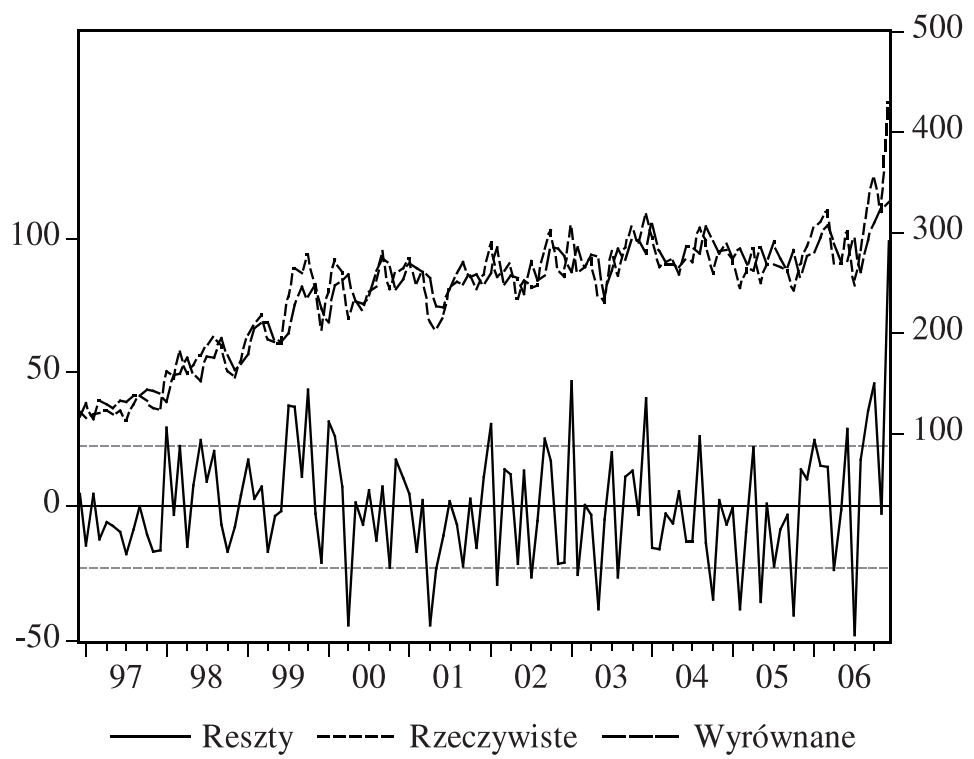

Wykres 7. Rzeczywiste i teoretyczne wartości fiskalnych kosztów pracy na 1 zatrudnionego miesięcznie w latach 1996-2006 ${ }^{6}$

Źródło: obliczenia własne.

Następny model autoregresyjno-trendowy, opisujący mechanizm zmienności dynamiki miesięcznych fiskalnych kosztów pracy netto, zredukował się do empirycznego modelu autoregresyjnego o postaci:

$$
\begin{aligned}
& \mathrm{fdn}_{\mathrm{t}}=9,832+0,604 \mathrm{fdn}_{\mathrm{t}-1}-0,254 \mathrm{fdn}_{\mathrm{t}-5}+0,343 \mathrm{fdn}_{\mathrm{t}-6}+0,244 \mathrm{fdn}_{\mathrm{t}-11}+\mathrm{u}_{2 \mathrm{t}} \text {, } \\
& (2,012) \quad(7,920) \\
& (2,492) \\
& (3,539) \\
& (3,056) \\
& \mathrm{R}_{2}^{2}=0,710 ; \mathrm{DW}_{2}=1,905 ; \mathrm{Su}_{2}=22,64 \text {. }
\end{aligned}
$$

Mechanizm autoregresyjny jest analogiczny, jak w przypadku modelu opisującego zmienną $\mathrm{fdb}_{\mathrm{t}}$. Nieco niższa jest jednak dokładność opisu zmian w modelu (2) w porównaniu z modelem (1). O ile w modelu (1) zmienność fiskalnych kosztów zatrudnienia brutto wyjaśniona została autoregresją na poziomie $85,5 \%$,

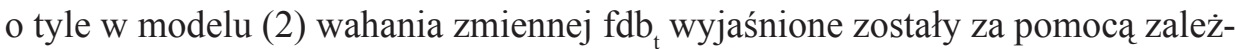
ności autoregresyjnych już tylko na poziomie 71,0\%.

${ }^{6}$ Na prawej osi rzędnych występują rzeczywiste i teoretyczne wielkości zmiennej fdb rażone jednopodstawowym indeksem dynamiki $(01.1996=100 \%)$, natomiast na osi lewej prezentowane są reszty modelu $\left(\mathrm{u}_{1 \mathrm{t}}\right)$. Analogiczna sytuacja występuje również na wykresie 6 . Wszelkie obliczenia w niniejszej pracy wykonane zostały za pomocą pakietu Eviews 4. 


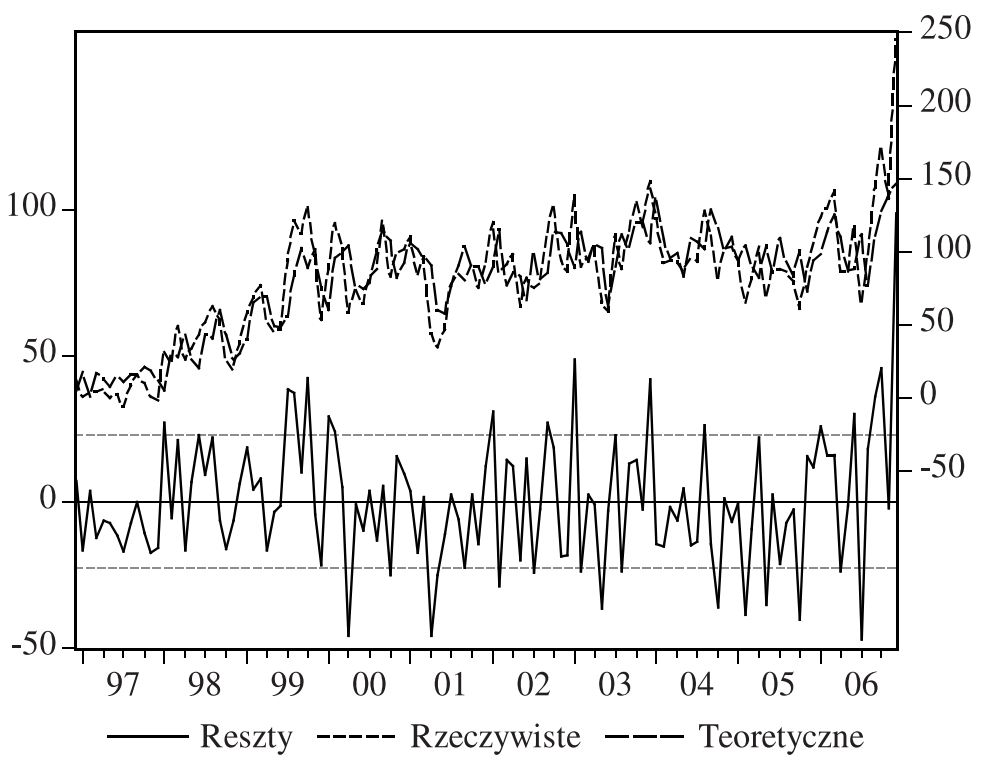

Wykres 8. Rzeczywiste i teoretyczne wielkości indeksu fiskalnych kosztów pracy na 1 zatrudnionego netto miesięcznie w latach 1996-2006

Źródło: obliczenia własne.

\section{FISKALNE OBCIĄŻENIA ZATRUDNIENIA A WYDAJNOŚĆ PRACY W MAŁEJ FIRMIE}

Występujące zmiany w fiskalnych obciążeniach zatrudnienia należy porównać z wahaniami zespołowej wydajności pracy. Warto zadać pytanie o udział fiskalnych kosztów zatrudnienia (w przeliczeniu na 1 zatrudnionego) w przeciętnej wydajności pracy miesięcznie. Wykres 7 ilustruje zmiany tego udziału w okresie 1996-2006. Dostrzega się systematyczny wzrost tegoż udziału, z określonymi wahaniami okresowymi.

W ciagu lat 1996-2006 procentowy udział fiskalnych kosztów zatrudnienia w wydajności pracy systematycznie wzrastał. W początkowym okresie wynosił on kilka procent, rosnąc do poziomu kilkunastu procent po roku 2000. Średnia wartość tego udziału wyniosła ponad 10\%. Najwyższe wskaźniki udziału pojawiły się od 2005 roku, przy czym maksymalny udział wyniósł 25,8\%. Szczegółowe informacje o strukturze udziału fiskalnych kosztów zatrudnienia w wydajności pracy prezentuje wykres 8 . Występująca tendencja zagraża więc - nawet $\mathrm{w}$ nieodległej perspektywie - istnieniu przedsiębiorstwa. 


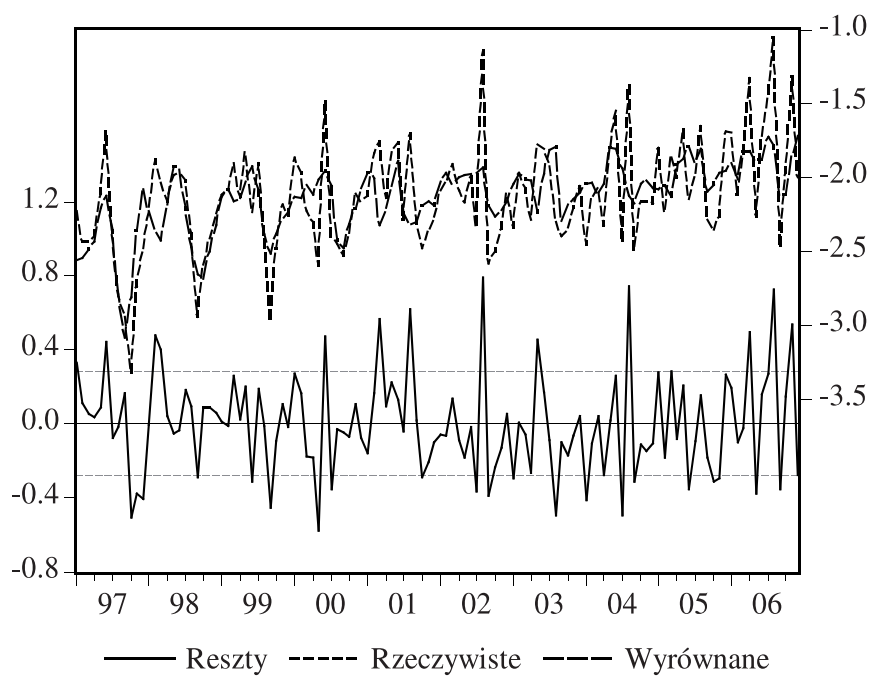

Wykres 9. Rzeczywiste i teoretyczne wielkości logitu udziału fiskalnych jednostkowych kosztów zatrudnienia $\mathrm{w}$ przeciętnej wydajności pracy miesięcznie w latach 1996-2006

Źródło: obliczenia własne.

Wreszcie model (3) opisuje mechanizm autoregresyjno-trendowy miesięcznych wahań udziału fiskalnych kosztów zatrudnienia w wydajności pracy. Zmienna lofiswyd ${ }_{t}$ jest logitem wskaźnika udziału fiskalnych kosztów zatrudnienia (w przeliczeniu na 1 pełnozatrudnionego) w jego wydajności pracy. W równaniu tym pojawiła się zmienna czasowa $\mathbf{t}$, $\mathbf{w}$ drugiej potędze, wskazując na występowanie trendu kwadratowego $\mathrm{w}$ zmiennej lofiswyd $\mathrm{t}_{\mathrm{t}}$.

$$
\begin{aligned}
& \text { lofiswyd }_{\mathrm{t}}=-1,364-0,194 \text { lofiswyd }_{\mathrm{t}-9}+0,243 \text { lofiswyd }_{\mathrm{t}-11}+ \\
& (5,412) \quad(2,703) \\
& (3,150) \\
& +0,336 \text { lofiswyd } \mathrm{t}_{\mathrm{t}-12}+0,0000153 \mathrm{t}^{2}+\mathrm{u}_{3 \mathrm{t}} \text {, } \\
& (4,509) \\
& (2,556) \\
& \mathrm{R}_{3}^{2}=0,426, \mathrm{DW}_{3}=2,254, \mathrm{Su}_{3}=0,281 .
\end{aligned}
$$

Powyższy model z umiarkowaną dokładnością opisuje prawidłowości autoregresyjno-trendowe logitu udziału fiskalnych kosztów zatrudnienia (w przeliczeniu na 1 pełnozatrudnionego) w wydajności pracy. Może jednak stanowić narzędzie kierunkowego prognozowania rozmiarów udziału fiskalnych kosztów zatrudnienia (w przeliczeniu na 1 pełnozatrudnionego) w jego wydajności pracy, stanowiąc instrument szacowania prognoz ostrzegawczych ${ }^{7}$. Może tym samym

7 Wykres 9 ilustruje rzeczywisty oraz opisywany przez model (3) mechanizm zmienności omawianego logitu oraz prezentuje reszty modelu autoregresyjno-trendowego. 
pomóc właścicielowi $\mathrm{w}$ podjęciu działań zabezpieczających przed spadkiem efektywności przedsiębiorstwa, przykładowo poprzez zmianę profilu działalności, zainwestowanie w nowszą technologię itd.

\section{PODSUMOWANIE}

Bezpieczeństwo ekonomiczne małego przedsiębiorstwa w dużym stopniu zależy od posiadania ważnych informacji statystycznych o kosztach i rezultatach własnej działalności. Ważna jest więc kultura informacyjna firmy, która w małym podmiocie zwykle jest na bardzo niskim poziomie. Znajomość prawidłowości kształtowania się kosztów pracy w firmie, w tym fiskalnych kosztów zatrudnienia, pozwala na podejmowanie racjonalnych decyzji dotyczących wszystkich ważnych obszarów życia przedsiębiorstwa. Informacje o tego typu mechanizmach winny być przedmiotem monitorowania przez organy władzy, które mogą modyfikować przepisy prawa w taki sposób, by powstrzymywać ewentualne upadłości firm, w tym również małych.

Przedstawione w niniejszej pracy trendy i mechanizmy występują w przedsiębiorstwach dość powszechnie. Kierunki następujących zmian winny nie tylko niepokoić świat polityki, ale też skłonić do refleksji nad stanem polskiej drobnej przedsiębiorczości. Racjonalne decyzje w sferze prawa mogą uchronić znaczącą dla systemu gospodarczego liczbę przedsiębiorstw przed kłopotami ekonomicznymi, a w konsekwencji przed upadłością.

\section{LITERATURA}

Wiśniewska E., Wiśniewski J.W. (2004), Ekonometryczna analiza rygorystycznych zobowiazań pieniężnych matego przedsiębiorstwa, [w:] Zarzeckiego D. (red.), Strategie wzrostu wartości przedsiębiorstwa, Uniwersytet Szczeciński, Szczecin, s. 985-994.

Wiśniewska E., Wiśniewski J.W. (2007), Ekonometryczne modelowanie płynności finansowej matego przedsiębiorstwa, Zarzeckiego D. (red.), Zarzadzanie finansami-Zarzqdzanie Ryzykiem i Kreowanie Wartości, Zeszyty Naukowe Uniwersytetu Szczecińskiego nr 455, Prace Instytutu Ekonomiki i Organizacji Przedsiębiorstw nr 50, t. II, Szczecin, s. 297-308.

Wiśniewska E., Wiśniewski J.W. (2007), Fiskalne uwarunkowania zapotrzebowania na prace $w$ malym przedsiębiorstwie, $O$ nowy tad podatkowy $w$ Polsce, [w:] Ostaszewskiego J. (red.),SGH, Warszawa, s. 463-472.

Wiśniewski J.W. (2002), Instrumenty decyzyjne przedsiębiorcy. Ekonometria stosowana, IW GRAVIS, Toruń (wyd. czwarte uzupełnione i poprawione).

Wiśniewski J.W. (2003), Ekonometryczny model małego przedsiębiorstwa, IW GRAVIS, Torun. 


\section{FISCAL COSTS OF EMPLOYMENT ON THE BACKGROUND OF WORK EFFICIENCY IN SMALL ENTERPRISE}

A b s t r a c t . The knowledge about mechanism of shaping costs of labour in the enterprise enables to undertake rationale decisions in its all-important areas. Information about these mechanisms should be the subject of interest of state and local government. These authorities are able to modify law regulations in such directions, which enable to prevent potential bankruptcy of many enterprises, small enterprises as well.

The trends and mechanism presented in this article take place in many enterprises quite usually. The directions of following changes should not only bother politicians but also incline to reflection about the condition of many small enterprises in Poland.

In the present study the trends and mechanisms of fluctuations of employment costs in small production enterprise have been presented. These trends were shown on the background of changes of corporate efficiency of labour. Empirical researches have been carried on the base of monthly data coming from 1996-2006. The study instrument was dynamic econometric model.

K e y w ords : fiscal costs of employment, work efficiency, small enterprise. 